\title{
Composition of Cassava (Manihot esculenta Crantz) and the Rheological Characteristics of its Starch $^{1}$
}

\author{
E. J. Rodriguez-Sosa, O. Parsi-Ros, and M. A. González²
}

\begin{abstract}
Proximate composition of two edible commercial varieties of cassava (M. esculenta Crantz) grown in Puerto Rico, and the rheological characteristics of their starch were determined. These included variety Pana which has a light tan skin and a dark-skinned variety known as Zenón, or Yuca Negra de Moca (Black Moca cassava), in the Dominican Republic.

Proximate composition was found to be about the same for both varieties. Hydrocyanic acid content was well below the toxicity level (50 to $100 \mathrm{mg} \mathrm{HCN} / \mathrm{kg}$ of fresh-peeled tuberous root). Although pasting temperatures were the same for both varieties $\left(63^{\circ} \mathrm{C}\right)$, viscosity values of the starch of Pana variety were somewhat higher than those of Zenón.
\end{abstract}

\section{INTRODUCTION}

Cassava ( $M$. esculenta Crantz) is a tuberous root crop extensively cultivated throughout the tropics. Even though its major use is as human food, it also is used as livestock feed and as a source of starch.

It is estimated that the diet of about 200 to 300 million people throughout the world includes cassava $(4,9)$, and world production is calculated at 92.2 million tons (16). During fiscal year 1973-74 the production of cassava in Puerto Rico was only about 80,000 cwt with a cash value of approximately $\$ 584,000$ (7).

The two most important varieties of cassava used in Puerto Rico are a light tan skinned variety known as Pana and a dark brown skinned variety known in the Dominican Republic as Zenón or Yuca Negra de Moca (Black Moca cassava). Although grown to a limited extent on the Island, most of the dark skinned variety consumed in Puerto Rico is imported from the Dominican Republic.

Cassava does not store well as a fresh vegetable because it develops a dark bluish discoloration or vascular streaking within a few days after harvesting. Puerto Rico's production of cassava could be increased if new and economic ways could be found to store it either as a fresh vegetable

1 Manuscript submitted to Editorial Board January 29, 1975.

${ }^{2}$ Assistant Food Technologist, Research Assistant and Technical Director, respectively, Food Technology Laboratory, Agricultural Experiment Station, Mayagüez Campus, University of Puerto Rico, Río Piedras, P.R. 
or as a processed product. To achieve this, knowledge of its starch and its chemistry are needed.

The composition of plants may vary greatly with variety, soil, fertilizers, climate, geographical location, and age of the plant $(5,20,23)$. Aside from water, starch is the most abundant constituent of the cassava root, ranging from 12 to $33 \%(6,20)$. The amylose content ranges from 16 to $30 \%(11,12,21)$. Extensive viscosity tests of cassava starch have been reported $(14,18,19,22)$, but no such tests seem to have been performed on varieties grown or consumed in Puerto Rico.

This paper presents some aspects of the composition of locally grown cassava roots; also viscosity measurements of the starches.

\section{MATERIALS AND METHODS}

Commercial samples of cassava were obtained on the local market. The varieties Pana and Zenón were used in this study.

For ash, fiber, protein, $\mathrm{Ca}, \mathrm{K}$ and $\mathrm{P}$ analysis, the roots were cut into small pieces and dehydrated in a forced-circulation oven at approximately $58^{\circ} \mathrm{C}$. The dried material was ground to 40 mesh $(0.420 \mathrm{~mm})$ in a Wiley mill ${ }^{3}$. Ash, fiber, and protein were determined following the methods of the AOAC (17). Ca and $\mathrm{K}$ were determined by flame emission using a Hitachi-Perkin Elmer Spectrophotometer with a flame photometer attachment. P was analyzed following the method of Fiske and Subbarow (8) as modified by Technicon Co.

Moisture was determined following the vacuum oven method (17) and ether extracts using a Soxhlet-type extractor (17). Total and reducing sugars, hydrocyanic acid (HCN), and starch content were determined on a wet weight basis. Total and reducing sugars were analyzed following the method of Mayer and Holgate (15). The starch and HCN were determined by the methods described by Carter and Neuber (2) and by Indira and Sinha (10), respectively.

To determine the amylose content of cassava the starch was isolated following the method of Badenhuisen (1). To ascertain the efficiency of the purification procedure, the purified starch was analyzed for ash, protein, fiber, and $\mathrm{pH}$. The $\mathrm{pH}$ was measured by mixing $20 \mathrm{ml}$ distilled water with $10 \mathrm{~g}$ dried starch. Ash, protein, and fiber were determined as explained above for dried cassava. The amylose content was determined following the method of McCready and Hassid (13).

The rheological characteristics of the extracted and purified starches were examined using the Brabender Amylograph-Viscograph. Samples

${ }^{3}$ Trade names are used in this publication for the sole purpose of providing specific information. Mention of a trade name does not constitute a guarantee or warranty of the equipment by the Agricultural Experiment Station of the University of Puerto Rico or an endorsement over other equipment not mentioned. 
were prepared by mixing $500 \mathrm{ml}$ distilled water with $27.5 \mathrm{~g}$ starch. The rotational speed of the instrument was adjusted to $75 \mathrm{r} / \mathrm{m}$ and the 700 $\mathrm{cm} / \mathrm{g}$ cartridge was used in the determinations. Initial viscosity of the mixture was recorded at ambient temperature $\left( \pm 26^{\circ} \mathrm{C}\right)$. The starch mixture was then heated to $30^{\circ} \mathrm{C}$ and the heating-cooling cycle initiated. The temperature was increased to $93^{\circ} \mathrm{C}$ at a constant rate of $1.5^{\circ} \mathrm{C} / \mathrm{min}$ and held at that temperature for $1 \mathrm{hr}$. Thereafter the temperature was

TABle 1.-Proximate composition of cassava (M. esculenta Crantz) of the Pana and Zenon varieties and the chemical composition of the isolated and purified starches

\begin{tabular}{|c|c|c|}
\hline \multirow{2}{*}{ Analysis } & \multicolumn{2}{|c|}{ Variety } \\
\hline & Pana & Zenón \\
\hline & $\%$ & $\%$ \\
\hline & Dry weight & \\
\hline Ash & 0.85 & 0.81 \\
\hline Fiber & 2.15 & 2.75 \\
\hline Protein $(\mathrm{N} \times 6.25)$ & 1.25 & 1.75 \\
\hline $\mathrm{Ca}$ & .15 & .15 \\
\hline $\mathrm{K}$ & .77 & 1.42 \\
\hline $\mathrm{P}$ & .08 & .17 \\
\hline \multirow[t]{2}{*}{ Ether extract } & .52 & .68 \\
\hline & Wet weight & \\
\hline Moisture & 57.93 & 68.08 \\
\hline Total sugar & 2.03 & 3.82 \\
\hline Reducing sugar & .69 & .53 \\
\hline $\mathrm{HCN}^{*}$ & 3.91 & 1.32 \\
\hline \multirow[t]{2}{*}{ Starch } & 22.95 & 22.19 \\
\hline & Compositiono & \\
\hline Ash & .03 & .01 \\
\hline Protein & .44 & .25 \\
\hline Fiber & 0 & 0 \\
\hline $\mathrm{pH}$ & 6.57 & 6.10 \\
\hline
\end{tabular}

$*$ Content is given in $\mathrm{mg} / 100 \mathrm{~g}$.

lowered to $50^{\circ} \mathrm{C}$ at the same rate and held there for another hour. Samples were run in triplicate.

\section{RESULTS AND DISCUSSION}

The proximate composition of the two varieties of cassava studied is presented in table 1. The HCN content was somewhat higher in the Pana variety. Nevertheless, its content was well below the established toxicity level (50 to $100 \mathrm{mg} \mathrm{HCN} / \mathrm{kg}$ of fresh-peeled root) (3).

The chemical analyses of cassava starches isolated for amylose 
determinations are shown in table 1 . The results demonstrated that the starches were pure enough to proceed with determination of amylose content, which was 13 and $21 \%$ for the Pana and Zenón roots, respectively.

The pasting characteristics of cassava starches are presented in table 2 , while figure 1 shows the graphical representation of those characteristics. Although pasting temperatures were the same for both varieties $\left(63^{\circ}\right.$ C), viscosity measurements were higher for the starch of the Pana variety. Rasper (19), working with four African-grown varieties, found pasting temperatures ranging from 63.7 to $69^{\circ} \mathrm{C}$.

Cassava starch showed a moderate peak viscosity on heating. This reflects the fragility of the swollen starch granules. The peak viscosity on

TABle 2.-Pasting characteristics of cassava (M. esculenta Crantz) starch slurries taken using the Brabender Amylograph-Viscograph

\begin{tabular}{|c|c|c|}
\hline \multirow{2}{*}{ Pasting measurement } & \multicolumn{2}{|c|}{ Variety } \\
\hline & Pana & Zenón \\
\hline & $B U^{i}$ & $B U$ \\
\hline Initial viscosity & 12 & 8 \\
\hline Pasting temperature $^{2}$ & 63 & 63 \\
\hline Maximum peak on heating & 507 & 298 \\
\hline Viscosity at $93^{\circ} \mathrm{C}$ & 415 & 296 \\
\hline Viscosity after 1 hr at $93^{\circ} \mathrm{C}$ & 202 & 137 \\
\hline Viscosity at $50^{\circ} \mathrm{C}$ & 440 & 348 \\
\hline Viscosity after $1 \mathrm{hr}$ at $50^{\circ} \mathrm{C}$ & 435 & 320 \\
\hline
\end{tabular}

${ }^{1}$ Brabender units.

${ }^{2}$ Temperature in ${ }^{\circ} \mathrm{C}$.

heating indicates the highest viscosity that the user might encounter during the preparation of a usable starch paste. As shown in figure 1 the starch of the Pana variety showed more fragility than the starch of the Zenón variety. The maximum viscosity on heating in the former variety was attained before reaching the maximum temperature, $93^{\circ} \mathrm{C}$. In the Zenón variety the maximum peak was attained at the same point of highest temperature in two of the replicates. In the other the maximum peak was attained just before ( $5 \mathrm{BU}$ ) the maximum temperature.

After the maximum peak, viscosity decreased until the end of the cooking period at $93^{\circ} \mathrm{C}$. Cassava starch of the Pana variety thinned down more rapidly and to a greater extent than that of the Zenon variety. This thinning indicates the stability or breakdown of the starch during cooking. The breakdown is produced by a fragmentation and solubilization of the swollen starch granules under the continuous mechanical agitation of the Amylograph. Due to this fact, starches with these 
characteristics need careful cooking and good agitation in order to pass through the viscosity peak and achieve a properly cooked paste.

When cassava starch hot paste was cooled to $50^{\circ} \mathrm{C}$, it tended to retrograde. This reassociation of the starch granules is shown by the increase in viscosity of the paste (fig. 1) with decreasing temperature. Retrogradation of Pana was somewhat higher than that of Zenón. Both retrograded by about the same number of units (238 and $211 \mathrm{BU}$ respectively).

A small decrease in viscosity was observed while the starch paste was being cooked at $50^{\circ} \mathrm{C}$ for $1 \mathrm{hr}$. This shows that cassava starch is stable at temperatures at which it might be regularly used.

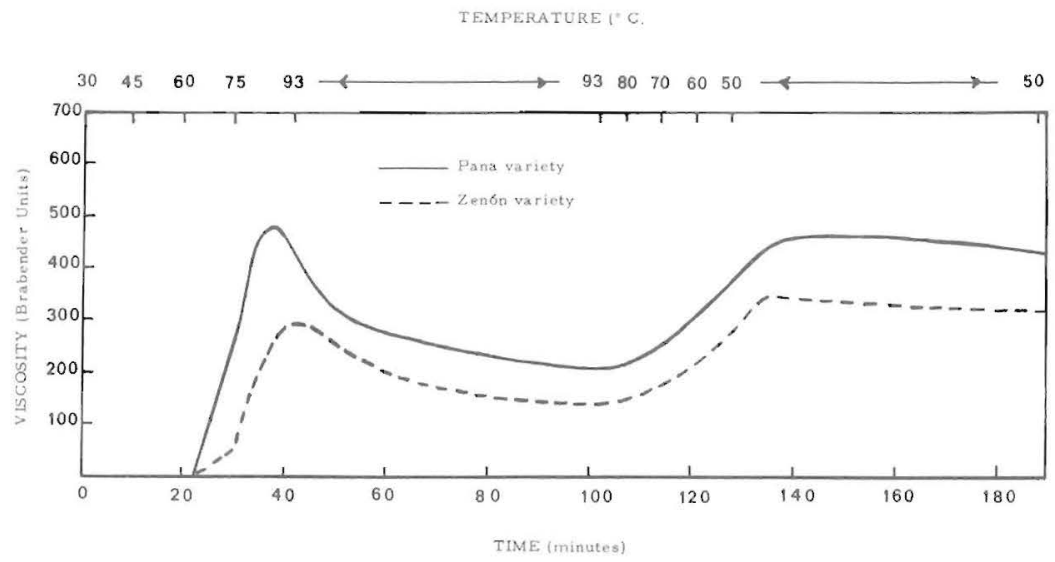

Fig. 1.-Typical viscosity curves of cassava (Manihot esculenta Crantz) starch as determined with the Brabender Amylograph-Viscograph.

There are only slight differences in components of the two varieties, while there are marked differences among some of the rheological properties of the starch of the two varieties. Variations in composition of raw materials are important to both food technologists and processors.

\section{RESUMEN}

La composición aproximada y las características reológicas del almidón se determinaron en las dos variedades de yuca de mayor consumo en Puerto Rico. La variedad Pana tiene la cáscara color castaño claro y la variedad conocida como Zenón o yuca negra de Moca la tiene castaño oscuro. Esta última se importa mayormente de la República Dominicana aunque se está cultivando en pequeña escala en Puerto Rico.

El contenido de ácido prúsico (HCN) en ambas fue mucho más bajo que el nivel tóxico establecido para el ser humano ( 50 a $100 \mathrm{mg}$. HCN/kg. de la raiz en estado fresco).

Las propiedades reológicas del almidón de ambas variedades se determinaron usando el amiloviscógrafo Brabender. La viscosidad a través de todo el ciclo fue más alta para la variedad Pana. El almidón de yuca es frágil, ya que al calentarse hasta $93^{\circ} \mathrm{C}$ muestra un 
pico de viscosidad. Por consiguiente, el almidón de yuca debe cocerse cuidadosamente removiéndolo bien para que la pasta condense apropiadamente.

\section{LITERATURE CITED}

L. Badenhuisen, N. P., Method in carbohydrate chemistry, R. L. Whistler, ed., Academic Press, New York, N.Y., Vol. IV: 14-5, 1964.

2. Carter, G. H., and Neubert, A. M., Rapid determination of starch in apples, J. Agr. Food Chem. 2(21): 1070-2, 1954.

3. Coursey, D. G., Chronic cassava toxicity, B. Nestel and R. MacIntyre, ed., Ottawa, Can. IDRC-010e: 27-36, 1973.

4. — and Haynes, P. H., Root crops and their potential as a food in the tropics, World Crops, pp. 261-5, 1970.

5. De Bruijn, G. H., Chronic cassava toxicity, B. Nestel and R. MacIntyre, ed.. Ottawa, Can. IDRC-010e: 43-8, 1973.

6. Edwards, D., The industrial manufacture of cassava products: An economic study. Trop. Prod. Inst., Chap. 1, May 1974.

7. Espinet, G., Personal Communication.

8. Fiske, S. H., and Subbarow, Y., Colorimetric determination of phosphorus, J. Biol. Chem. 66(2): 375-400, 1925.

9. Food and Agricultural Organization of the United Nations, Production Yearbook, Rome, p. $814,1968$.

10. Indira, P., and Sinha, S. K., Colorimetric method for determination of HCN in tubers and leaves of cassava (Manihot esculenta Crantz), Indian J. Agr. Sci. 39(11): 1021-3, 1969.

11. Johnson, R. M., and Raymond, W. D., The chemical composition of some tropical food plants. IV. Manioc, Trop. Sci. 7(3): 109-15, 1965.

12. Ketiku, A. O, and Oyenuga, V. A., Changes in the carbohydrate constituents of cassava root-tuber (Manihot utilissima Pohl) during growth, J. Sci. Fed. Agr. 23(2): $1451-6,1972$.

13. McCready, R. M., and Hassid, W. Z., The separation and quantitative estimation of amylose and amylopectin in potato starch, J. Amer. Chem. Soc. 65: 1154-7, 1943.

14. Mazurs, E. G., Schoch, T. J., and Kite, F. E., Graphical analysis of the Brabender viscosity curves of various starches, Cereal Chem. 34(3): 141-52, 1957.

15. Moyer, J. C., and Holgate, K. C., Determination of alcohol-insoluble solids and sugar contents of vegetables, Anal. Chem. 20(5): 472-4, 1948.

16. Nestel, B., Chronic cassava toxicity. B. Nestel and R. MacIntyre, ed., Ottawa, Can. IDRC-010e: 11-26, 1973.

17. Official Methods of Analysis of the Association of Official Agricultural Chemist, 10th ed, Washington, D.C., 1965.

18. Rasper, V., Investigation on starches from some West African root crops, Proc. Int. Symp. Trop. Root Crops, Univ. W. Indies, St. Augustine, Trinidad, Vol. 2 (Sec. VI): $48-59,1967$.

19. - Investigations on starches from major starch crops grown in Ghana. I. Hot paste viscosity and gel-forming power, J. Sci. Fed. Agr. 20(3): 165-71, 1969.

20. Shipman, I.., Starch: Chemistry and technology. Vol. 2, Industrial aspects, R. L. Whistler and E. F. Paschall, ed., Academic Press, New York, N.Y., pp. 103-19, 1967.

21. Velikaya, E. I., and Nguen Din'Tkhyong, Physico-chemical properties of manioc starch. Food Sci. Technol. Abstr. 4(5): 106, 1972.

22. Waldt, L. M., and Kehoe, D., Starch chemistry for the food technologist, Food Technol. 13(1): 1-4, 1959.

23. Zuber, M. S., Starch: Chemistry and technology. Vol. 1, Fundamental aspects, R. L. Whistler and E. F. Paschall, ed., Academic Press, New York, N.Y., 43-63, 1965. 